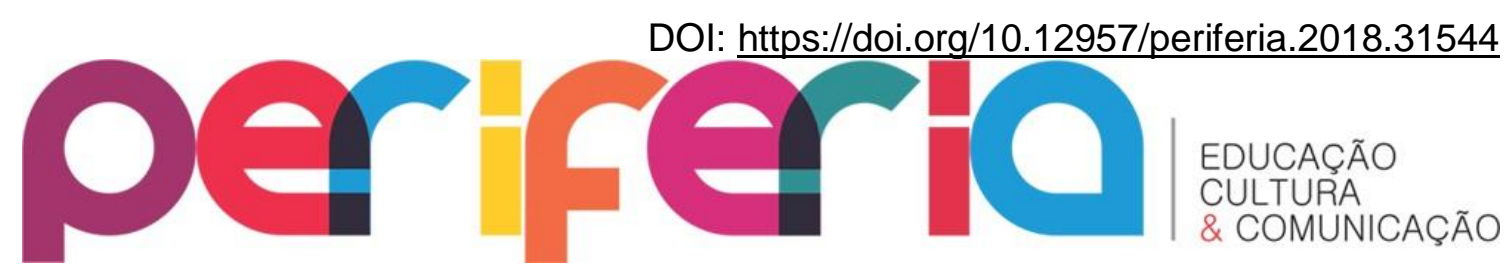

\title{
IDENTIDADE RELIGIOSA DO MÉDIUM SURDO NO TERREIRO DE MINA - JEJE NAGÔ HUEVY EM BELÉM - PARÁ
}

\section{RELIGIOUS IDENTITY OF THE MÉDIUM DEAF IN THE MINA TERRITOR - JEJE NAGÔ HUEVY IN BELÉM - PARÁ}

\author{
Sergio Mauricio de Oliveira Junior ${ }^{1}$ \\ Silvio Santiado-Vieira ${ }^{2}$ \\ Jakson dos Santos Ribeiro ${ }^{3}$
}

\begin{abstract}
RESUMO: A presente pesquisa teve como objetivo compreender a representação simbólica das guias (Ogum, Iemanjá e Xangô) na construção da identidade religiosa do médium Surdo na Casa Grande de Mina Jeje Nagô de Toy Lissá e Abê Manjá Huevy, pertencente ao Tambor de Mina. Para o desenvolvimento do trabalho foi aplicado o método etnográfico. Nesse sentido, observou-se que a identidade religiosa do indivíduo estudado é constituída de inúmeros fatores, sendo que as guias e a sua representação simbólica, configuram-se como um fator principal na constituição identitária do médium Surdo, visto a sua percepção visuo-espacial. Nota-se que as guias são elementos simbólicos que institui ao médium Surdo uma significação religiosa para o entendimento da sua identidade, pois, identificou-se que a espiritualidade desse sujeito pesquisado é evidenciada com o uso das guias para confirmação das suas práticas religiosas no terreiro no qual ele está inserido.
\end{abstract}

PALAVRAS-CHAVE: Guias. Identidade Religiosa. Surdo.

ABSTRACT: The present research has as main objective to understand the symbolic representation of the guides (Ogum, Iemanjá and Xangô) in the construction of the

\footnotetext{
1 Discente do curso de Licenciatura em Ciências da Religião da Universidade do Estado do Pará (UEPA/CCSE). Este é fruto de uma pesquisa iniciada no segundo semestre de 2016, vinculada ao Grupo de Estudos Surdos \& Interfaces (GESI) do Instituto de Educação e Cultura do Pará (IEPA) e financiada pelo Programa de Bolsas de Pesquisa do IEPA. E-mail: juni.oliver33@gmail.com

2 Mestrando em Ciências das Religiões (PPGCR/FUV). Professor de Educação Especial/Libras Departamento de Ensino Especializado (DEES) da Universidade do Estado do Pará (UEPA). Coordenador do Grupo de Estudos Surdos \& Interfaces (GESI/IEPA). E-mail: saintvier@gmail.com

${ }^{3}$ Doutorando em História Social da Amazônia (PPHIST/UFPA). Professor do Departamento de História e Geografia, Curso de História da Universidade Estadual do Maranhão (UEMA). Vice-Coordenador do Grupo de Estudos Surdos \& Interfaces (GESI/IEPA). E-mail: noskcajzaionnel@gmail.com
} 


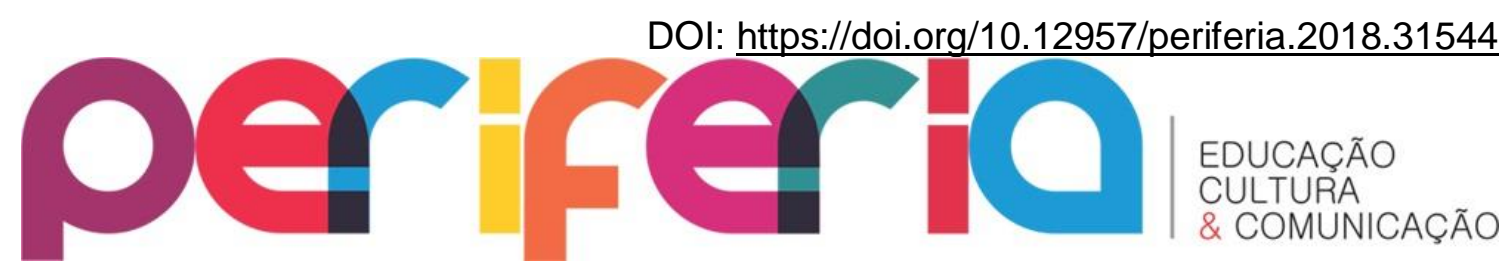

religious identity of the Deaf medium in the Great House of Mina Jeje Nagô of Toy Lissá and Abê Manjá Huevy, belonging to the Mine Drum. For the development of the work the ethnographic method was applied with direct observation of the Deaf medium in the middle of the rituals, interview and audio-visual record. In this sense, it was observed that the religious identity of the individual studied is made up of innumerable factors, and the guides and their symbolic representation are a major factor in the identity constitution of the Deaf medium, given his visuo-spatial perception. It is noted that the guides are symbolic elements that establishes to the medium Deaf a religious significance for the understanding of their identity, because, it was identified that the spirituality of this subject is evidenced with the use of guides to confirm their religious practices in the terreiro In which it is inserted.

KEYWORDS: Guides. Religious Identity. Deaf.

\section{INTRODUÇÃO}

Atualmente, observam-se inúmeros avanços no cenário científico, em todas as áreas do conhecimento. No ponto de vista das Ciências da Religião, o fenômeno religioso tornou-se objeto de pesquisa para se compreender as várias manifestações do sagrado e como este se relaciona com a sociedade.

O Brasil é um país destacado pela sua diversidade cultural, especialmente quando se refere às tradições religiosas, onde muitas dessas denominações ainda são pouco conhecidas (as religiões afro-brasileiras, as religiões indígenas, as religiões da nova era, etc.), pois, os estudos realizados no campo acadêmico ainda são muito recentes.

Diante desse panorama, esta pesquisa objetiva compreender aspectos importantes do universo cultural afro-brasileiro e do $\mathrm{Surdo}^{4}$, que ainda são pouco conhecidos, com o enfoque pautado na construção da identidade religiosa do indivíduo em questão, adepto da religião denominada como Tambor de Mina, a partir das representações simbólicas das guias, de acordo com a visão de mundo construída em um ambiente cujos saberes são transmitidos via oral-visual.

Para estudar esse fenômeno, foi necessário primeiramente, compreender o indivíduo Surdo de acordo com a perspectiva visual, pois essa reflete e molda formas de entendimento acerca dos seus aspectos socioculturais. Nessa perspectiva, esse elemento se tornou o meio do contato direto com o indivíduo pesquisado e também outros Surdos.

${ }^{4}$ Conforme defende Sacks (1998), aos que se enquadram nos modelos "audistas" - os surdos que não são culturalmente surdos - são indicados com "s" minúsculo, relativa à surdez auditiva; os "Surdos" com "s" maiúsculo, portanto, são aqueles formadores de uma entidade linguística e cultural. Para saber mais, ver: SACKS, Oliver. Vendo vozes: uma jornada pelo mundo dos surdos. Tradução Alfredo B.P. de Lemos. Rio de Janeiro: Imago, 1998.

Revista Periferia, v.10, n.1, p. 100 - 119, Jan./Jun. 2018 


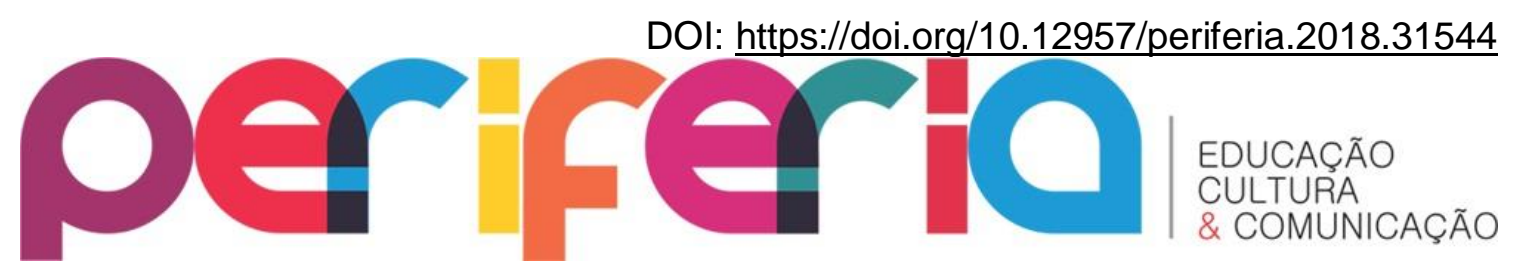

Além de servir como ponto de partida para a compreensão sobre o outro, baseada na alteridade, para conhecer as diferenças entre ouvintes e surdos.

Em seguida, foi imprescindível, portanto, obter o conhecimento sobre o Tambor de Mina, principalmente em relação ao ethos presente no lócus dessa pesquisa, cujo nome é Casa Grande de Mina Jeje Nagô de Toy Lissá Abê Manjá Huevy, que está localizado na região periférica de Belém do Pará. Então, suscita-se que a religião reflete no seu meio social, um conjunto de representações que participa na construção do Eu religioso.

Esse âmbito religioso, já proporcionou a presença de sete Surdos, mas atualmente, evidencia-se a presença de apenas dois membros Surdos, sendo que o objeto central pesquisado foi aquele que já concluiu o processo iniciático o qual será denominado como "médium Surdo".

O médium Surdo utiliza a Língua Brasileira de Sinais, caracterizada como emergente $^{5}$, mas também utiliza a leitura labial e a modalidade escrita, com ressalvas, para a tentativa de comunicação com os indivíduos ouvintes do âmbito religioso. Ele está inserido no terreiro de mina desde 2004 e já completou todo o seu processo iniciático, onde em um determinado período realizou a "feitura" dos três orixás (Ogum, Iemanjá e Xangô) e finalizou esse processo com a feitura da Tobossi.

Nesse processo iniciático, realizou-se a confecção das guias, que se configuram como relevante na constituição identitária do médium Surdo, onde elas são adereços fundamentais juntamente com a estética do terreiro, sendo que essas possuem representações simbólicas através das variadas expressões e performances que geram significados lógicos.

Segundo Correia ${ }^{6}$ (2009) é por meio da estética que as religiões transparecem o seu "sentido", o seu "saber" e a sua "expressividade". Assim se estabelece a visão de mundo dos indivíduos Surdos, em meio ao grupo sociocultural inserido, onde através de associações, por meio da empiria, buscam apresentar, representar, expressar, aprender, ensinar, entender, compreender e comunicar.

Para o desenvolvimento dessa pesquisa foi aplicado, em grande parte, o método etnográfico, sendo que também se utilizou, em vários momentos, o método fenomenológico, ambos proporcionaram o uso de técnicas de observação direta do médium Surdo em meio aos rituais, entrevistas (este procedimento foi aplicado somente por meio da Língua Brasileira de Sinais, incluindo a presença de interprete) e registros audiovisual.

É relevante ressaltar que todas as informações necessárias não foram obtidas exclusivamente com o médium Surdo, devido à sua utilização da língua de Sinais emergente, que dificultou ao indivíduo a compreensão da sinalização realizada pelo interprete que utilizou a língua de sinais formal. Nesse caso, foi imprescindível realizar entrevista com outro indivíduo surdo, usurário da Libras formal, que também já

\footnotetext{
${ }^{5}$ Língua de sinais emergente está relacionado ao uso de uma comunicação entre surdos e familiares surdos ou ouvintes, popularmente conhecida como língua de sinais caseira.

${ }^{6}$ CORREIA, Paulo Petronilio. Agô Orixá! Gestão de uma Jornada Afro-estética-trágica: o relato de um aprendizado e de uma formação pedagógica vivida no candomblé. Porto Alegre, 2009.
}

Revista Periferia, v.10, n.1, p. 100 - 119, Jan./Jun. 2018 


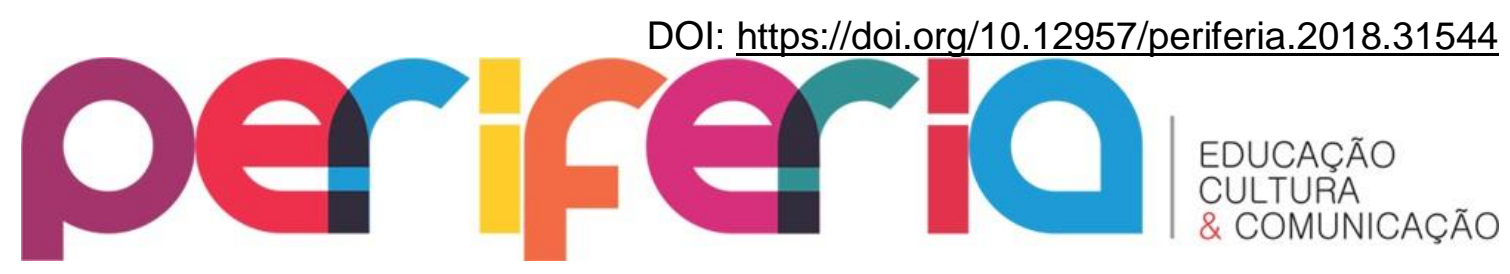

participou dos rituais do mesmo terreiro de mina e mantém contato com o médium Surdo pesquisado.

\section{1 - ORIXÁS E SUAS RESPECTIVAS GUIAS: CONCEPÇÕES SURDAS}

O Tambor de Mina é uma religião afro-brasileira considerada popular do Brasil que, encontra-se fortemente presente no estado do Maranhão, mas também pode ser presenciada (devido aos processos migratórios) em várias regiões brasileiras, como no Estado do Pará, na cidade de Belém, onde está localizado o lócus dessa pesquisa. Para Ferretti (2000, p. 61) a religião "é um culto a entidades espirituais africanas 'Voduns e Orixás' que baixam na cabeça de seus filhos, nos 'toques' (rituais públicos, com tambor)."

Assim como as demais religiões afro-brasileiras, o Tambor de Mina reflete no seu meio social um conjunto de representações como os valores, os ensinamentos, os costumes, a culinária, a língua, as diferentes manifestações do sagrado no seu cotidiano, assim como a visão do Eu individual e coletivo. Conforme defende Buber $^{8}$ (2012), a identidade, o "eu", está fundada no encontro entre dois parceiros (Iodeto ou Eu- Ele Divino), na reciprocidade e na confirmação mútua, que assume a essência do encontro, do diálogo, na relação $e u$-tu.

Essas expressões são caracterizadas como ethos, que segundo Geertz (2008, p. 93), indica "o tom, o caráter e a qualidade de sua vida, seu estilo moral e estético, e sua disposição é a atitude subjacente em relação a ele mesmo e ao seu mundo que a vida reflete" $"$.

Entretanto, essa concepção de ethos está intimamente relacionada com a visão de mundo, que Geertz considera como "a imagem elaborada das coisas como elas são na simples realidade, seu conceito de natureza, de si mesmo, da sociedade" 10 .

A partir da lógica empregada por Geertz (2008), pode-se utilizá-la para iniciar o entendimento sobre a visão de mundo da pessoa Surda, sendo necessário primeiramente explicar o termo "Surdo". Para (Sá, 2002) observa-se que:

Quanto ao termo "surdo", podemos dizer que é o termo com o qual as pessoas que não ouvem referem-se a si mesmos e a seus pares. Podemos definir uma pessoa surda como aquela que vivencia um déficit de audição que o impede de adquirir, de maneira natural, a língua oral/auditiva usada pela comunidade

\footnotetext{
${ }^{7}$ FERRETTI, Mundicarmo Maria Rocha. Desceu na Guma:o caboclo do tambor de mina de São Luís - A Casa Fanti-Ashanti. $2^{\text {a }}$ Ed. São Luís: Edufma, 2000.

${ }^{8}$ BUBER, Mantin. Eu e tu. Tradução, introdução e notas de Newton Aquiles Von Zuben. 10. ed. rev. São Paulo: Centauro, 2012.

${ }^{9}$ GEERTZ, Clifford. A Interpretação das Culturas. - 1d. 13reimpr. - Rio de Janeiro: LTC, 2008.
}

${ }^{10}$ GEETZ, 2008, p. 93. 


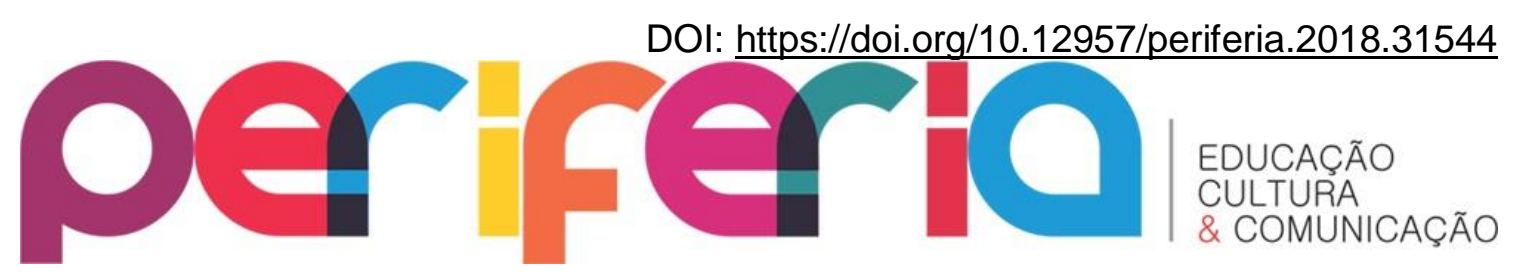

majoritária e que constrói sua identidade calcada principalmente nesta diferença, utilizando-se de estratégias cognitivas e de manifestações comportamentais e culturais diferentes da maioria das pessoas que ouvem. (SÁ, 2002, p. 49) ${ }^{11}$

Então, a surdez está presente, no contexto contemporâneo, nos estudos culturais, pois, para Behares apud Schelp (2009, p. 2287) "cremos que é nela que se baseia a essência psicossocial da surdez: ele (o surdo) não é diferente unicamente porque não ouve, mas porque desenvolve potencialidades psicoculturais diferentes das dos ouvintes"12. Essas potencialidades permitem que o indivíduo surdo crie mecanismos diferentes de atribuir significados e identidades as coisas, de acordo com sua visão de mundo.

No que tange a identidade religiosa do médium Surdo, o Tambor de Mina reflete um conjunto de representações que está expresso nas suas vivências, adquiridas nos ensinamentos aprendidos no cotidiano do terreiro. Isso se observa quando o médium surdo diz que "aqui no terreiro eu aprendi observando e, foi muito difícil no início porque as pessoas oralizavam e escreviam, mas eu não entendia a maioria das informações". Nota-se que a observação foi o mecanismo chave para a assimilação dos ensinamentos.

No terreiro de Mina Jeje Nagô, espaço desta pesquisa, cada membro religioso, médiuns ouvintes e o médium Surdo, possuem formas distintas de entender o sagrado a partir dos ensinamentos que são transmitidos. Para os médiuns ouvintes a aprendizagem ocorre nas vivências por meio da oralidade. Para o médium Surdo, esses ensinamentos adquiridos também são assimilados pelas vivências no cotidiano do terreiro, mas sucede-se de acordo com a sua percepção visuo-espacial.

Partindo dessa percepção, notou-se que o médium surdo se comunica, principalmente, através de língua de sinais e, por meio dela, expressa o conhecimento adquirido sobre as guias que representam os seus Orixás. Este conhecimento obtido através da sua experiência médium no terreiro contribuiu para a transposição das informações por meio da descrição de características marcantes das representações simbólicas, em especial, por meio das representações imagéticas, representações performáticas e pela contextualização de fatos empíricos.

Desse modo, o médium surdo se utiliza, também, de ambas as características de representações simbólicas para expressar o sagrado e seus fenômenos. A partir da noção de sagrado para o médium Surdo, destaca-se, primeiramente, a sua percepção sobre os

${ }^{11}$ SÁ, Nídia Regina Limeira de. Cultura, poder e educação de surdos. Manaus: Universidade Federal do Amazonas. 2002.

12 SCHELP, Patrícia Paula. Pensar o Presente da Educação de Surdos a Partir de Leituras e Interpretações do Passado: perspectivas de inclusão nas escolas de ensino regular. Londrina, 2009. (Anais do V Congresso Brasileiro Multidisciplinar de Educação Especial). 


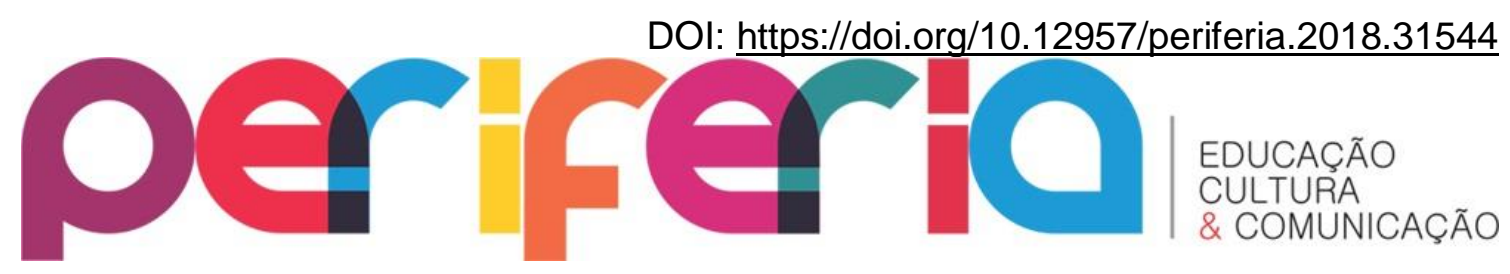

Orixás, especialmente Ogum, Iemanjá e Xangô para mais adiante estabelecer as relações com as suas respectivas guias.

No terreiro de Mina Jeje Nagô Huevy, os fragmentos míticos retratam os Orixás como deuses ligados a natureza que estão personificados, ou seja, na sua forma antropomórfica e a percepção do médium surdo sobre os Orixás se procedeu através das representações performáticas que estão contidas em expressões imagéticas no espaço sagrado, sendo que estas possuem fragmentos de mitos evidenciados nas pinturas artísticas, nos enfeites decorativos, nas estátuas, nas vestes, nos adereços, na culinária, no bailar e no transe; sendo que estes aspectos em sua essência são muito utilizados para reavivar algo relacionado ao cosmos dos Orixás.

Estes fragmentos míticos tornaram-se um recurso fundamental utilizado pelo médium Surdo para narrar, expressar, atribuir e/ou representar fatores importantes que exprimem o "cosmos transcendental", não apenas sobre os fenômenos produzidos dentro do seu grupo religioso, mas também sobre fenômenos da natureza e/ou sobrenaturais.

Diante das "potencialidades" desenvolvidas pelo médium Surdo, que permitem a contínua construção de sua identidade religiosa, pode-se demonstrar o sentido do sagrado, que emerge à luz da Surdez, sobre os Orixás como Ogum, Iemanjá e Xangô para então descrever a relação com as suas respectivas guias.

\section{$1.1-$ OGUM}

Ogum foi o primeiro a ser assentado no Ori $e$ isso foi realizado dentro do processo iniciático do médium surdo. Para ele "Ogum é o exímio guerreiro feroz com a armadura nas cores azul e branca, demonstra coragem e força, ele também manipula o ferro, possui habilidades com armas de batalha e é um grande guerreiro". Também se observou, por meio da pesquisa, alguns dos principais aspectos de Ogum para associá-lo a sua guia:

A relação quanto às cores - $\mathrm{O}$ médium Surdo associa as cores que representam Ogum, principalmente na armadura de batalha e a cor que representa a sua guia, sendo que está o identifica como filho desse Orixá.

A relação quanto à sensitividade - Ele identifica a energia de Ogum e em alguns momentos, sente a mesma energia emanada na guia.

A relação quanto à proteção - Identifica Ogum como seu protetor, então a guia tem a função de proteção espiritual e age contra enfermidades.

A relação quanto ao respeito - Por ser filho de Ogum, então o reverencia como forma de respeito, logo também presta reverência à guia. 


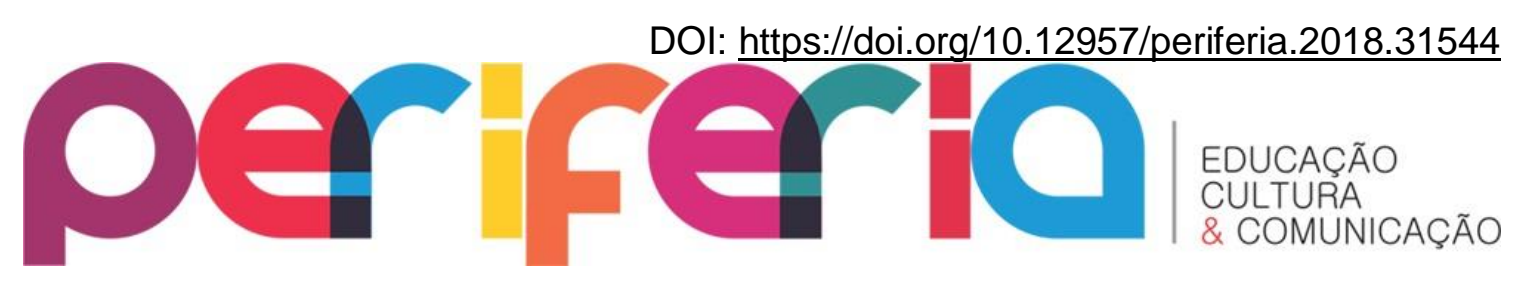

\section{2 - IEMANJÁ}

Já Iemanjá foi a segunda a ser assentada no Ori e isso foi realizado dentro do processo iniciático do médium Surdo. Para ele, "Iemanjá é a grande senhora das águas do mar, possui enorme beleza, sutileza, delicadeza e suas vestes são nas cores azul claro e branca, sendo que em sua coroa há contas de brilhante que descem pelo seu rosto". Então, ele observa alguns dos principais aspectos de Iemanjá para associá-la a sua guia:

A relação quanto às cores - Associa não apenas as cores que representam Iemanjá, principalmente nas vestes, mas também as cores do mar e as cores das contas de cristais presentes na sua coroa com as mesmas cores que representam a sua guia, sendo que está o identifica como filho desse Orixá.

A relação quanto à sensitividade - Identifica a energia de Iemanjá e em alguns momentos, sente a mesma energia emanada na guia.

A relação quanto à proteção - Identifica Iemanjá como sua protetora, então a guia tem a função de proteção espiritual e age contra enfermidades.

A relação quanto ao respeito - Por ser filho de Iemanjá, então a reverencia como forma de respeito, logo também prestará reverência à guia.

\section{3 - XANGÔ}

Por último, Xangô foi o terceiro assentado no Ori e isso foi realizado dentro do processo iniciático do médium Surdo. De acordo com o indivíduo surdo, "Xangô é o Orixá do fogo e do trovão, mas também é o rei das pedras, onde demonstra postura de realeza, o senhor da justiça, carrega dois machados como arma e as cores de suas vestes são em vermelho e branco". Então, ele observa alguns dos principais aspectos de Xangô para associá-lo a sua guia:

A relação quanto às cores - Associa as cores que representam Xangô, principalmente nas vestes e nas pedreiras com as cores que representam a sua guia, sendo que está o identifica como filho desse Orixá. 


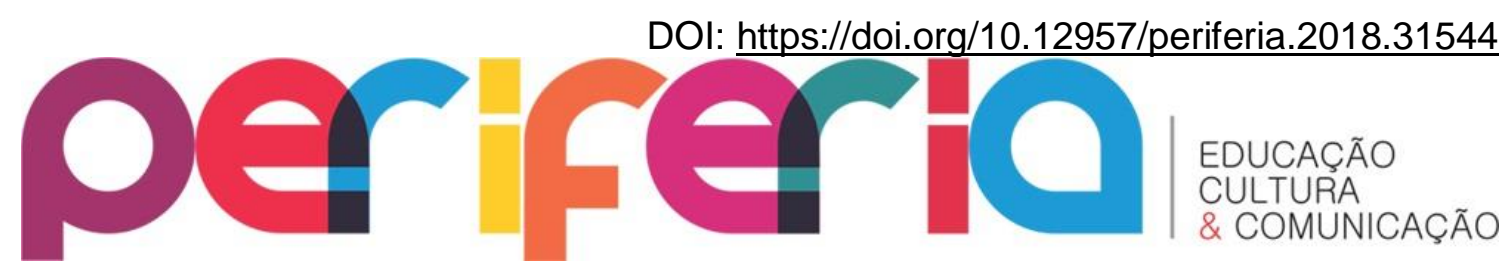

A relação quanto à sensitividade - Identifica a energia de Xangô e em alguns momentos, sente a mesma energia emanada na guia.

A relação quanto à proteção - Identifica Xangô como seu protetor, então a guia tem a função de proteção espiritual e age contra enfermidades.

A relação quanto ao respeito - ele por ser filho de Xangô, então o reverencia como forma de respeito, logo também prestará reverência à guia.

Abaixo, segue o quadro demonstrativo apresentando as cores das guias utilizadas pelo médium Surdo.

Quadro 1 - Cores das guias utilizadas pelo médium surdo

\begin{tabular}{|l|l|}
\hline Orixá & Cores das contas e balizas \\
\hline Ogum & Azulão leitoso com balizas na mesma cor \\
\hline Iemanjá & $\begin{array}{l}\text { Transparente cristal e azul claro translúcido com } \\
\text { balizas nas mesmas cores }\end{array}$ \\
\hline Xangô & $\begin{array}{l}\text { Marrom e branco com balizas vermelhas e azulão ou } \\
\text { vermelho e branco com balizas nas mesmas cores }\end{array}$ \\
\hline
\end{tabular}

\section{2 - A RELAÇÃO ENTRE AS GUIAS DOS ORIXÁS E MÉdIUM SURDO: REPRESENTAÇÕES A PARTIR DA COMUNICAÇÃO E APRENDIZAGEM}

As "guias", "fio de contas" ou "colares" são adereços estéticos fundamentais em rituais afro-brasileiros, destacando-se por sua beleza, no qual representam relações entre indivíduos e sagrado (representação das divindades africanas e proteção espiritual) e também relações entre indivíduos no dia-a-dia dos espaços sagrados.

Faz parte da identificação visual os filhos de Santo, o uso de colares, também conhecidos como guias, fios de conta ou colares. São geralmente produzidos com miçangas. As cores podem indicar desde quem são os Orixás da pessoa, sua idade

Revista Periferia, v.10, n.1, p. 100 - 119, Jan./Jun. 2018 


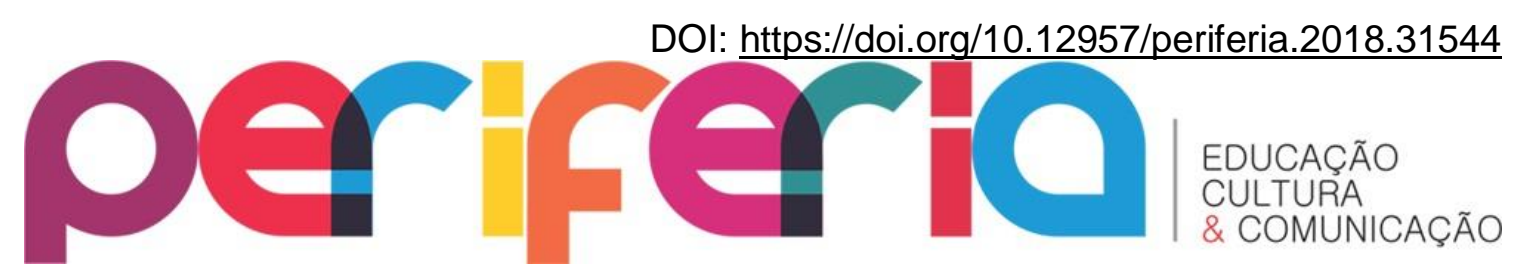

iniciática, sua hierarquia dentro do Terreiro e até mesmo, sua "nação" religiosa. (SILVA, 2016. p. 21) ${ }^{13}$.

Para entender as representações das guias no Tambor de Mina, especificamente as utilizadas pelos membros do terreiro é necessário, primeiramente, reconhecer que o seu processo de confecção é um ritual mágico traçado pelo próprio praticante. Grande parte do "povo do santo" desse terreiro já passou por esse processo. É imprescindível frisar que é nesse momento que se efetua na prática os ensinamentos adquiridos na vivência do cotidiano do terreiro.

Nesse sentido, nota-se que a elaboração da guia vai adquirir o significado simbólico cujas características estarão correlacionadas com elementos místicos. Para Correia (2009) cada fio de conta tem uma pedagogia, uma história e uma geografia própria na medida em que desenha, assinala, marca o orixá e a posição hierárquica no terreiro. A confecção das guias está pautada em ensinamentos e organizada da maneira que possam expressar representações simbólicas do sagrado. Esse processo se estabelece como um ritual.

O ritual é um sistema cultural de comunicação simbólica. Ele é constituído de seqüências ordenadas e padronizadas de palavras e atos, em geral expressos por múltiplos meios. Estas seqüências têm conteúdo e arranjos caracterizados por graus variados de formalidade (convencionalidade), estereotipia (rigidez), condensação (fusão) e redundância (repetição). (PEIRANO, 2003. p. 11) $)^{14}$.

Nesse ritual podem estar contidos alguns ritos, que são compreendidos como ensinamentos: estrutura e organização das contas (miçangas, cristais, pedras, sementes), pontos cantados, orações, canalização de energias, essências, ervas, entre outros. Esse

13 SILVA, Reginaldo Conceição da. "Na Gira da Umbanda": exercício etnográfico sobre expressões de afrorreligiosidade na "fronteira" e no Terreiro da Cabocla Jurema em Tabatinga, Amazonas. Dissertação (Mestrado) - Curso de Cartografia Social e Política da Amazônia, Universidade Estadual do Maranhão. São Luís, 2016.

${ }^{14}$ PEIRANO, Mariza. Rituais Ontem e Hoje. São Paulo: Jorge Zahar, 2003.

Revista Periferia, v.10, n.1, p. 100 - 119, Jan./Jun. 2018 


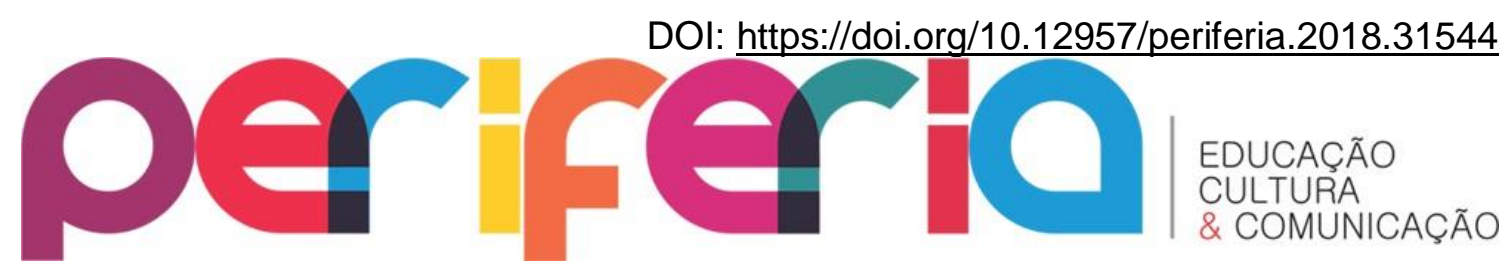

processo também se caracteriza como um "rito de passagem", para ascensão no status dos indivíduos dentro do núcleo religioso pertencente.

Sobre rito de passagem, Fäber (2013, p. 5) diz que "diante desta realidade os grupos se reorganizam e o rito de passagem de um indivíduo passa a externar, também, a não pertença de outro indivíduo ao grupo"15.

A referida autora, ainda tratando sobre o rito de passagem, retrata que:

Afirma Bourdieu que, ritos de passagem mais se aproximam de ritos de instituição pela sua função social e o efeito que lhe é consequente. Para o autor, o rito de instituição, como deveria ser chamado, demarca o momento vivencial do sujeito do rito ao mesmo tempo em que o diferencia dos demais, especialmente dos que não ascenderam a esse status ${ }^{16}$.

A confecção das guias é um procedimento que deve ser realizado pelo próprio membro religioso, visto que, esse método faz parte da dinâmica do terreiro para que novos membros possam entender melhor a sua espiritualidade e os sentidos simbólicos dentro desse espaço religioso.

É valido mencionar que as guias, após a sua consagração, passam a conter a áurea do sagrado, ou seja, adquirem a energia do Orixá, sendo que esse fator sobrenatural é destacado como mana. Para Mauss "O mana é a força por excelência, a eficácia verdadeira das coisas, que corrobora, sem aniquilar, a ação mecânica delas"17 (MAUSS, 2003, p. 145).

Sobre o ritual de confecção das guias, o médium Surdo realizou o mesmo percurso traçado pelos médiuns ouvintes, ou seja, ele mesmo confeccionou todas as suas guias: "Eu confeccionei todas as guias que utilizo" (Médium Surdo, 2017). Isso indica que ele também cumpriu as etapas no decorrer desse percurso. Assim como todo ritual é composto de ritos, este concretizado pelo médium surdo também conteve alguns

\footnotetext{
${ }^{15}$ FÄBER, Sônia Sirtoli. Hermenêutica do Rito: de interpretado a interprete. In: Congresso Estadual de Teologia. São Leopoldo: EST, v. 1 (Anais), 2013.

${ }^{16}$ FÄBER, 2013, p. 8

17 MAUSS, Marcel. Sociologia e Antropologia. Título original: Sociologie et Anthropologie. Tradução: Paulo Neves - São Paulo: Gosac Naify, 2003.
} 


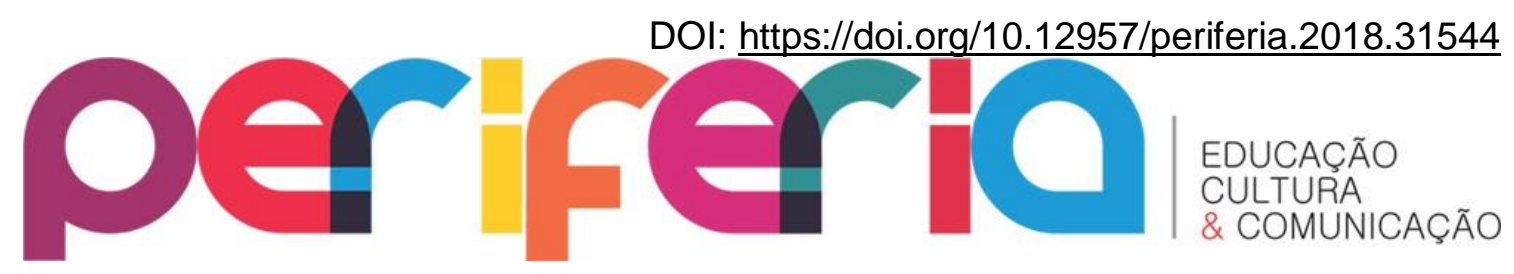

ritos essenciais. Dessa forma, pode-se caracterizar que tais métodos estão relacionados aos saberes do cotidiano presente no âmbito religioso do terreiro.

Para adentrar nos relatos do ritual de confecção e também entender a representação simbólica das guias para o médium Surdo, destaca-se a relevância de compreender como as informações foram transmitidas e como o indivíduo as assimilou.

Através da pesquisa de campo, observamos que os processos de assimilação das informações para que o médium surdo pudesse adquirir os ensinamentos sobre o espaço religioso, e mais especificadamente as representações simbólicas nos rituais de confecção e uso das guias, foram diversas, como por exemplo, a escrita da Língua Portuguesa, oralização, leitura labial, observação, associações, mímicas e Libras; este último em contextos restritos, pois não se observou nenhum interprete de Libras ou ouvinte falante da Libras, membro do terreiro. Em sua maioria, essas formas de comunicação, segundo Skliar (2005, p. 15) "trata-se de um conjunto de representações dos ouvintes, a partir do qual o surdo está obrigado a olhar-se e a narrar-se como se fosse ouvinte" $" 18$.

As tentativas de transmissão das informações ensinadas para o médium surdo sofreram alguns entraves devido às modalidades comunicacionais empregadas, oral e escrita (língua portuguesa), onde ele não conseguia compreender, devido diferenças culturais entre a comunicação ouvintista e surda, onde ambas necessitam de contextualização, só que a comunicação ouvintista é estabelecida através do canal oralauditivo e a comunicação surda se configura de maneira visuo-espacial, proporcionando barreiras comunicativas.

Esse fato é presenciado em seu relato: "O pai-de-santo, a mãe-de-santo e outra senhora escreviam as informações. Eles oralizavam entre si, eu ficava sempre calado, ai eles me davam papeis com informações escritas e eu não entendia nada”. (Médium Surdo, 2017)

Nota-se entre o médium Surdo e os ouvintes, membros do terreiro, a existência de percalços quanto às estratégias educativas no processo de comunicação, sendo que este processo é o elemento chave nas relações entre indivíduos. O terreiro é um espaço onde há uma pedagogia relacionada às práticas vividas e a ação de aprender-ensinar com o outro, pois, desde o início da trajetória do médium surdo no terreiro, ele se

${ }^{18}$ SKLIAR, Carlos. Os Estudos Surdos em Educação: problematizando a normalidade. In: SKLIAR, Carlos (Org.). A Surdez - Um Olhar Sobre as Diferenças. Porto Alegre: Mediação, 2005. 


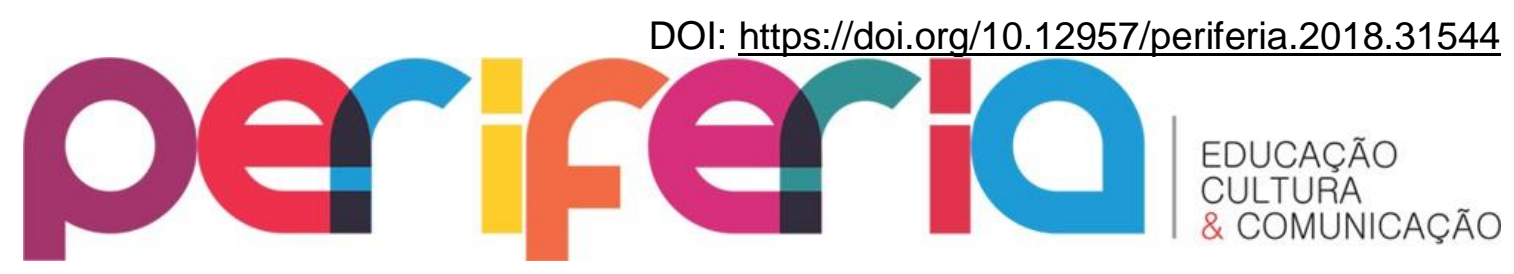

deparou com outras formas de percepção da realidade, evidenciando a diferença entre as culturas envolvidas, que culminou em novos meios para alcançar os sentidos produzidos na comunicação.

O processo de confecção das guias é entendido pelo médium Surdo como complexo, pois, exige muita atenção, organização e concentração: "tive muito trabalho, foi muito oneroso para mim e tive que fazer guia a guia”. (Médium Surdo, 2017)

Em outro momento, o médium surdo diz outra particularidade acerca das guias: "as minhas guias não podem ser utilizadas por outras pessoas, por que as guias possuem a minha identidade", e a partir dessa percepção, evidencia-se que as guias são de uso exclusivo do indivíduo que as confeccionou, sendo que a questão identitária religiosa presente nesses adereços não estão apenas retratando aspectos do sagrado (como um dos fundamentos da religião), mas construindo uma representação imagética concreta dos seus orixás. Outro aspecto notório dentro da fala do médium surdo identificou-se que o uso das guias é compreendido como símbolos de posse, visto que ele as confeccionou para seu uso, na condição do seu "ser religioso", então pertence apenas a si mesmo.

\section{3 - A RELAÇÃO ENTRE AS GUIAS E LIBRAS: REPRESENTAÇÕES TERMINOLÓGICAS NA LÍNGUA BRASILEIRA DE SINAIS}

O estudo desenvolvido neste momento apresenta à proposta da utilização de terminologias, empregada no terreiro de Mina Jeje Nagô Huevy, nesse caso, especificamente na Libras. Dessa forma, apresenta-se com finalidade de interrelacionar os objetos secundários dessa pesquisa como a Libras. Os termos selecionados para compor um glossário foram divididos nas seguintes categorias:

Quadro 2 - Categorias e terminologias utilizadas no glossário

\begin{tabular}{|l|l|}
\hline Categorias & Termos \\
\hline Orixá & Ogum, Iemanjá, Xangô \\
\hline Guia & $\begin{array}{l}\text { Guia de Ogum, Guia de Iemanjá, Guia de } \\
\text { Xangô }\end{array}$ \\
\hline Religião & Tambor de Mina, Afro-religioso, Sagrado \\
\hline Espaço Sagrado & Ritual, Incorporação/Transe, Proteção, \\
\hline
\end{tabular}




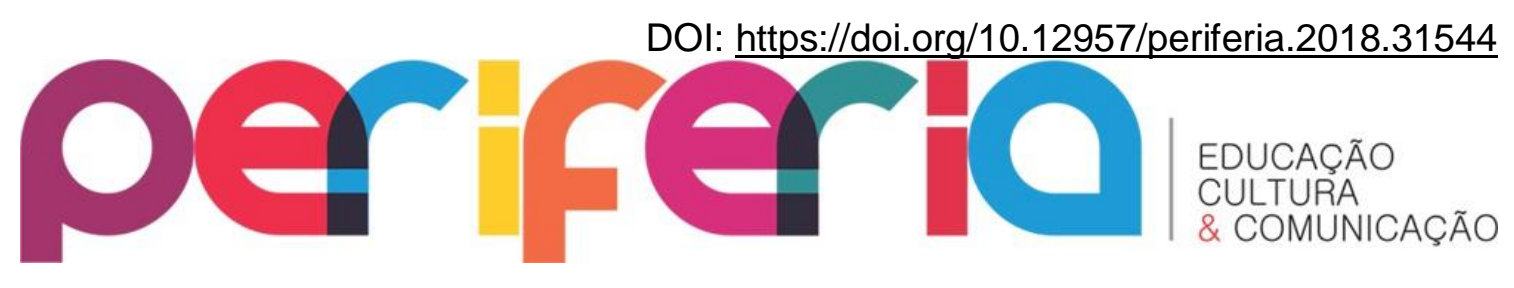

Terreiro, Gira.

As categorias e termos são apresentados como proposta de amenizar a carência de sinais e/ou para a substituição de termos incoerentes e pejorativos que foram aplicadas as religiões afro-brasileiras, nesse caso, especificamente no Tambor de Mina. De acordo com Monteiro et. al. (2016) ${ }^{19}$, após a análise de bancos terminológicos em Libras, especialmente em dicionários, evidenciou-se que:

Uma das características do dicionário Capovilla é a existência de poucos sinais de outras vertentes religiosas [...] Portanto foi verificado que no devido dicionário existe a ausência de sinais representando outras religiões, visando compreender a diversidade religiosa, já que no dicionário encontram-se somente sinais das religiões cristãs. Por mais que o dicionário contenha alguns sinais de outra vertente religiosa, o mesmo realizado ou feito de maneira que acabar reforçando o preconceito dentro da comunidade surda ${ }^{20}$.

Vale frisar que o dicionário CAPOVILLA. F.C.; RAPHAEL, W.D.; MAURICIO, A.C.L.. NOVO DEIT-LIBRAS: Dicionário Enciclopédico Ilustrado Trilíngue da Língua de Sinais Brasileira (Libras) ${ }^{21}$ é uma referência de banco terminológico da Libras. Partindo dos estudos de Monteiro et al (2016), pode-se afirmar a ausência de sinais sugeridos para as religiões afro-brasileiras, em especial o Tambor de Mina. Dessa forma, tivemos a preocupação de organizar um glossário, com o intuito de contribuir com a comunidade $\operatorname{Surda}^{22}$ na desconstrução de preconceitos e

${ }^{19}$ MONTEIRO, Ana Eloisa Lima, CONCEIÇÃO, Damaris de Jesus Silva da, RAMOS, Fabíola Carolina da Costa, CUNHA, Jackeline da Silva, MELO, Suellem de Carvalho. Terminologias na perspectiva da Libras com foco na criação de sinais na área das ciências da religião. In: III COLÓQUIO DO PPGCR/UEPA Belém: PPGCR/UEPA (Anais), pp. 17-25, 2016

${ }^{20}$ MONTEIRO et al, 2016, p. 06).

${ }^{21}$ CAPOVILLA. F.C.; RAPHAEL, W.D.; MAURICIO, A.C.L.. NOVO DEIT-LIBRAS: Dicionário Enciclopédico Ilustrado Trilíngue da Língua de Sinais Brasileira (Libras). 2 vol. Editora EDUSP, 2013

${ }^{22} \mathrm{~A}$ referência é feita àqueles frequentadores (surdos e ouvintes) de associações, clubes de surdos, igrejas, escolas, entre outros, nos quais essa diferença é demarcada como resistência às imposições das ideologias oralistas nos movimentos políticos por eles organizados. Assim, esses movimentos são os responsáveis diretos pela "gestação da política da identidade Surda" (PERLIN, 2001, p. 69) que denuncia processos sociais e educativos centrados na fala e na audição, nomeando suas "manifestações culturais" Para saber

Revista Periferia, v.10, n.1, p. 100 - 119, Jan./Jun. 2018 


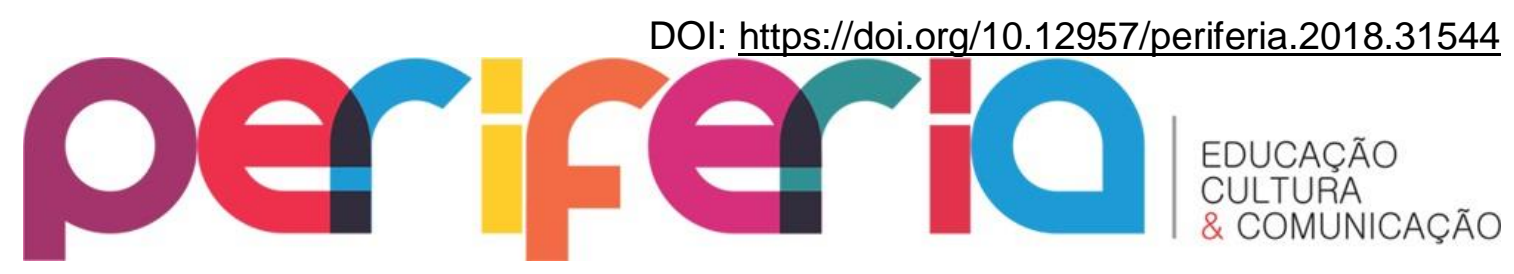

estereótipos enraizados no imaginário não apenas dos indivíduos ouvintes, mas também dos Surdos

Para a criação dos sinais referente aos Orixás, o médium Surdo baseou-se da seguinte forma:

Quadro 3 - informações sobre a criação de sinais para os Orixás

\begin{tabular}{|l|l|}
\hline \multirow{5}{*}{ Ogum } & $\begin{array}{l}\text { O médium surdo utilizou-se de aspectos } \\
\text { marcantes através da observação para } \\
\text { criar identificação lógica de acordo com a } \\
\text { Língua de Sinais. A expressão } \\
\text { performática de Ogum, quando } \\
\text { incorporado (transe) em meio aos rituais, } \\
\text { o médium surdo utilizou a expressão de } \\
\text { manejo das armas de batalha para criar o } \\
\text { sinal específico para este Orixá. }\end{array}$ \\
\hline Iemanjá & $\begin{array}{l}\text { O médium surdo utilizou-se de aspectos } \\
\text { marcantes de Iemanjá presentes nas } \\
\text { representações imagéticas e performáticas. } \\
\text { Através da observação, o mesmo utilizou- } \\
\text { se de expressões suaves representando o } \\
\text { transe, os aspectos femininos e as ondas } \\
\text { do mar. Estes recursos utilizados para } \\
\text { criar identificação lógica especifica para } \\
\text { este Orixá de acordo com a Língua de } \\
\text { Sinais. }\end{array}$ \\
\hline Xangô & $\begin{array}{l}\text { Em relação a este Orixá, o médium surdo } \\
\text { utilizou-se de aspectos marcantes através } \\
\text { para criar uma identificação adequada na } \\
\text { Língua de Sinais. A expressão } \\
\text { performática de Xangô no processo de } \\
\text { incorporado (transe) em meio aos rituais, } \\
\text { o ele utilizou a expressão simbolizando os } \\
\text { machados usados pela divindade. }\end{array}$ \\
\hline
\end{tabular}

mais, ver: PERLIN, Gladis. Identidades Surdas. In: Skliar, Carlos. et al. A Surdez: um olhar sobre as diferenças. Porto Alegre: Mediação, 2001. $2^{\mathrm{a}}$ ed. p. 51-73.

Revista Periferia, v.10, n.1, p. 100 - 119, Jan./Jun. 2018 


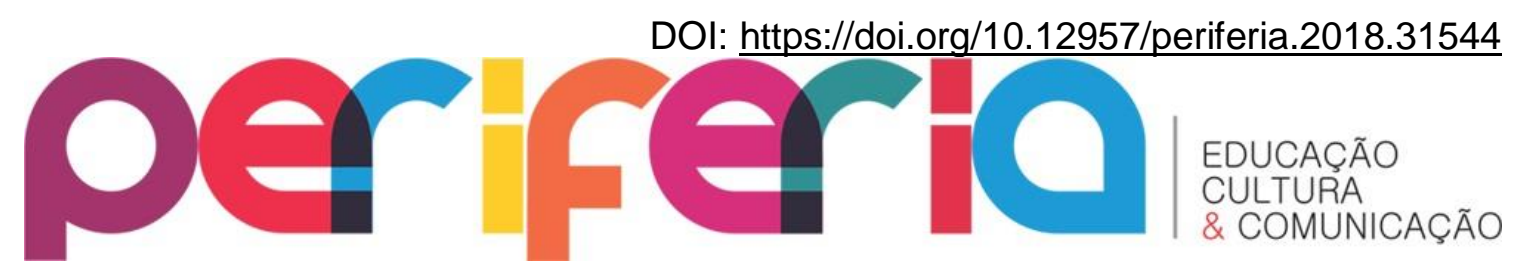

Para a criação dos sinais referente às guias, o médium Surdo baseou-se da seguinte forma:

Quadro 4 - informações sobre a criação de sinais para as guias

\begin{tabular}{|l|l|}
\hline A Guia de Ogum & $\begin{array}{l}\text { O sinal criado pelo mesmo para identificar } \\
\text { a guia de Ogum nángua de Sinais, está } \\
\text { diretamente relacionado pela letra inicial } \\
\text { do nome do Orixá "o", que contorna a } \\
\text { guia traçando a posição de uso com a } \\
\text { expressão de força, simbolizando a } \\
\text { característica guerreira dessa divindade. }\end{array}$ \\
\hline A Guia de Iemanjá & $\begin{array}{l}\text { Em relação à guia que representa Iemanjá, } \\
\text { o sinal criado pelo mesmo está } \\
\text { relacionado com a primeira letra do nome } \\
\text { da divindade que se inicia com a letra "i", } \\
\text { gesticulando para simbolizar as ondas do } \\
\text { mar na posição de uso da guia. }\end{array}$ \\
\hline A Guia de Xangô & $\begin{array}{l}\text { sinal criado pelo médium Surdo para } \\
\text { atribuir a guia de Xangô, está relacionado } \\
\text { com o nome da divindade, expressa na } \\
\text { primeira letra "x", gesticulando para } \\
\text { contornar a este adereço de acordo com a } \\
\text { posição de uso. }\end{array}$ \\
\hline
\end{tabular}

Esta pesquisa proporcionou a elaboração de um glossário, onde está contido o significado dos itens principais abordados juntamente com a catalogação de novos sinais, como proposta de novos termos para a comunidade Surda e também estabelecer a reflexão sobre os sinais já existentes que não transpõe de forma clara ou adequada de acordo com o objeto que o representa.

GLOSSÁRIO DE SINAIS-TERMOS DO TAMBOR DE MINA DA NAÇÃO JEJE NAGÔ 

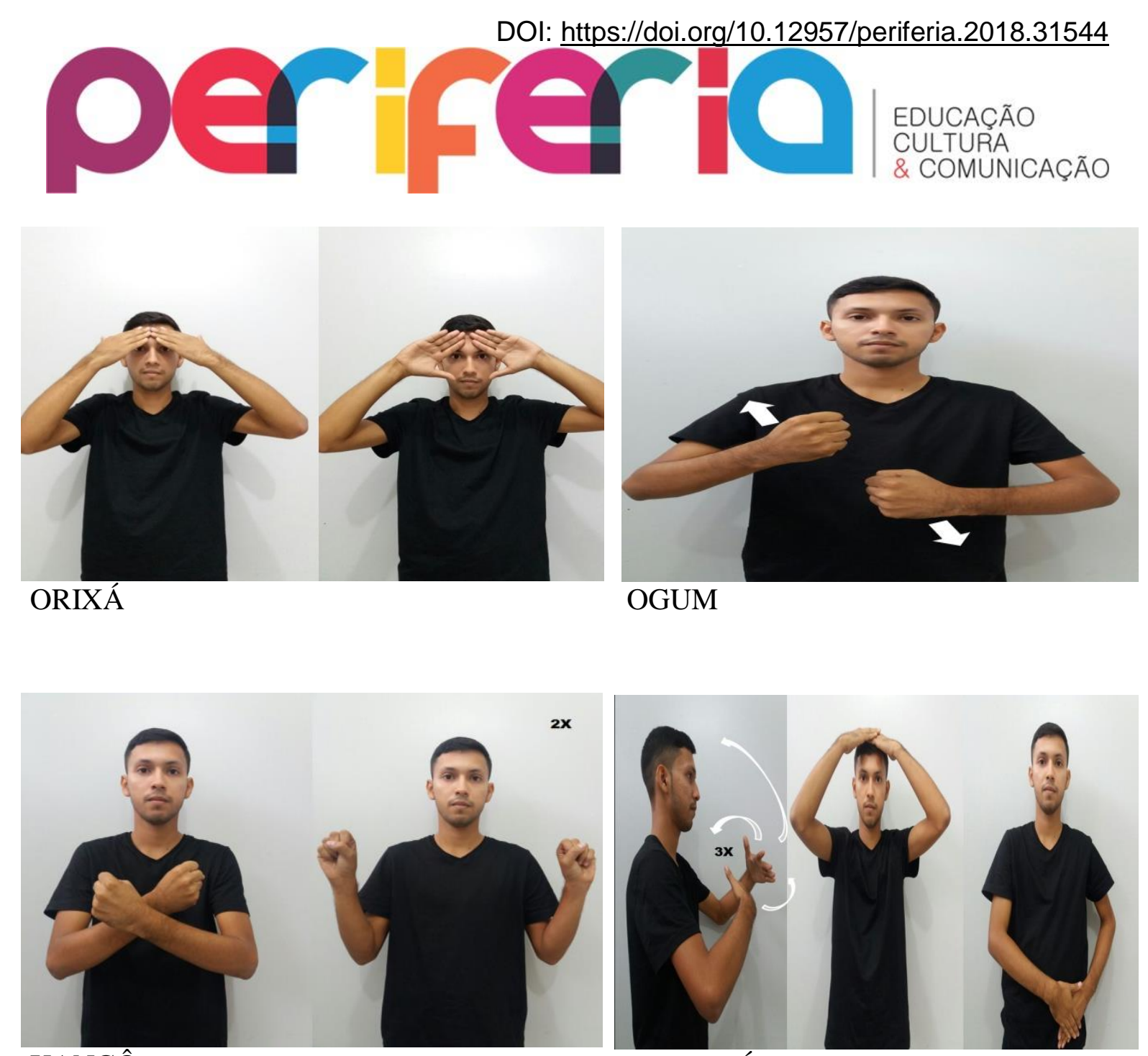

XANGÔ

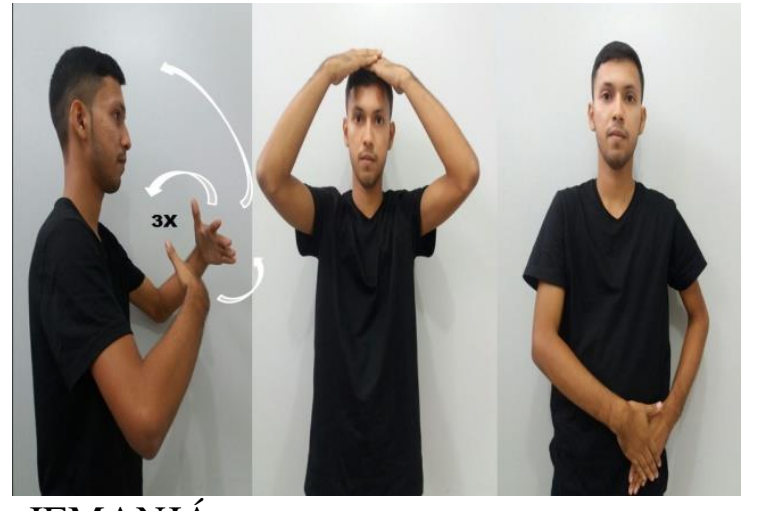

IEMANJÁ
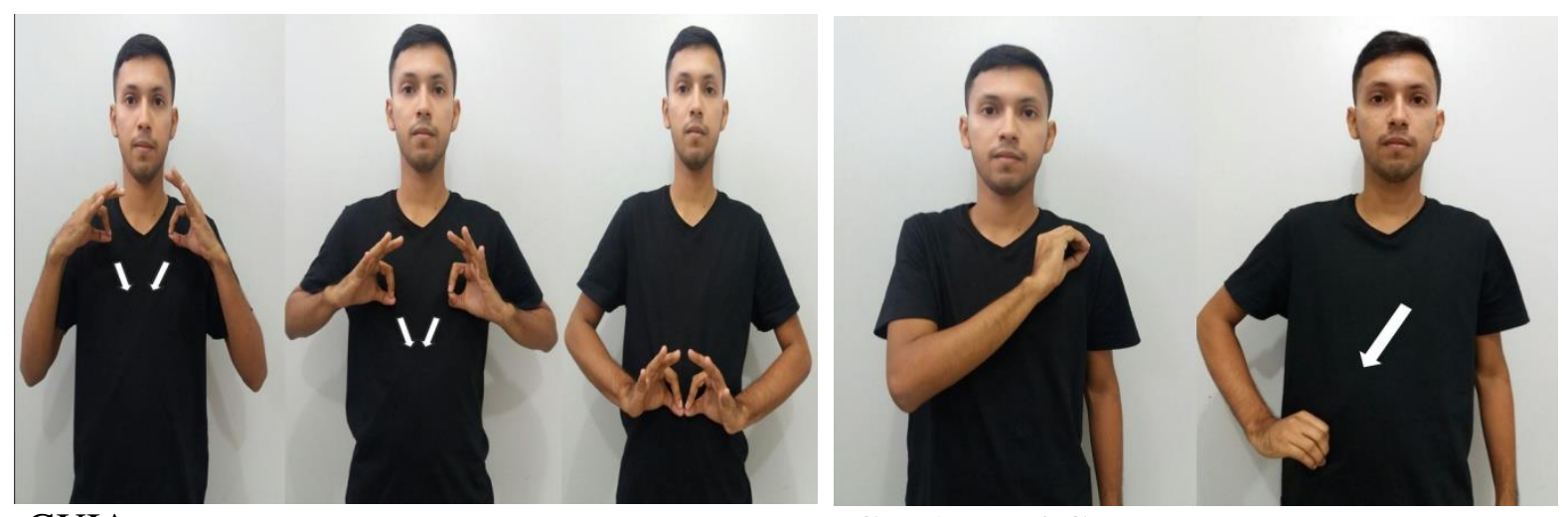

GUIA

GUIA DE OGUM

Revista Periferia, v.10, n.1, p. 100 - 119, Jan./Jun. 2018 

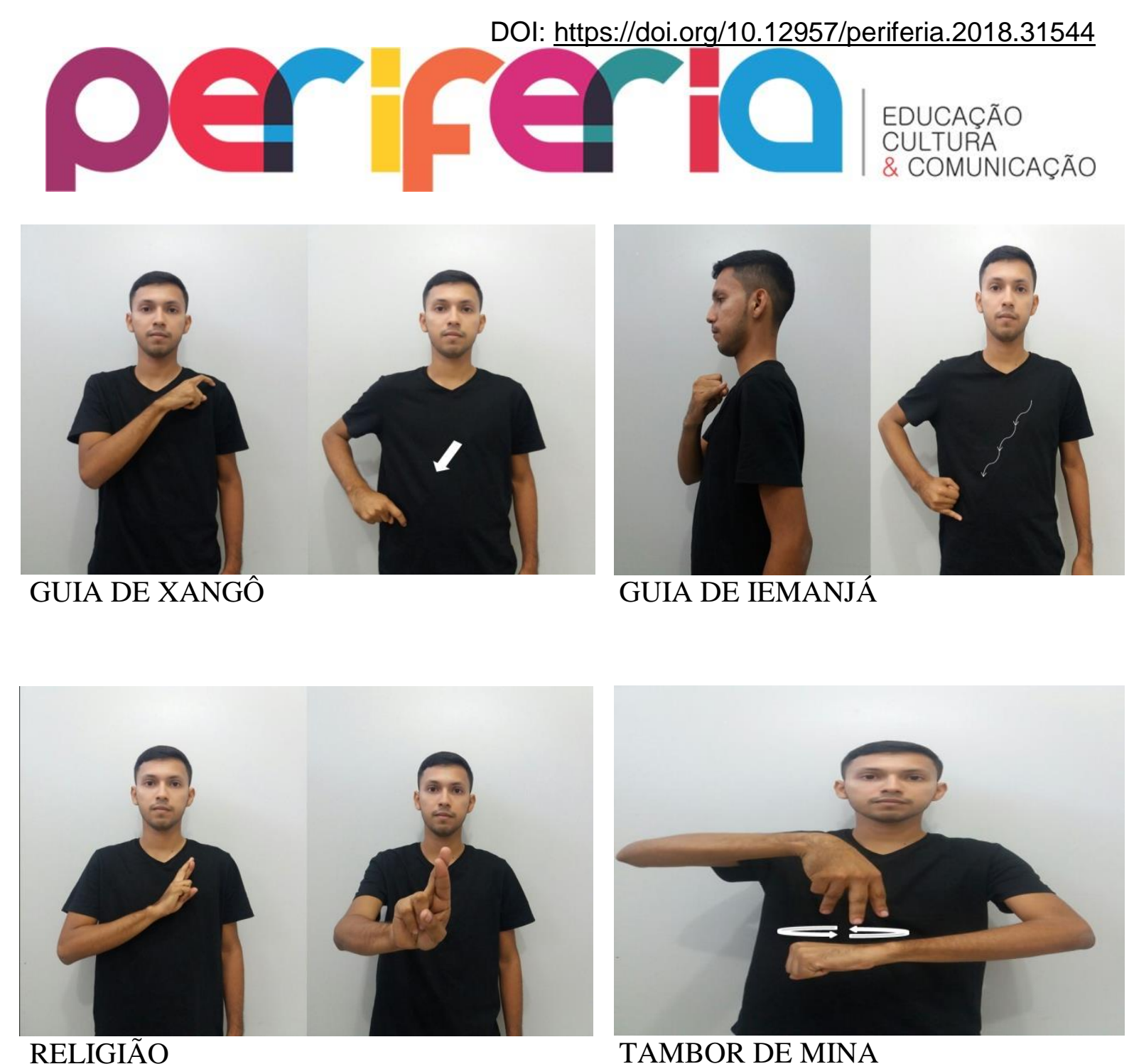

RELIGIÃO

TAMBOR DE MINA

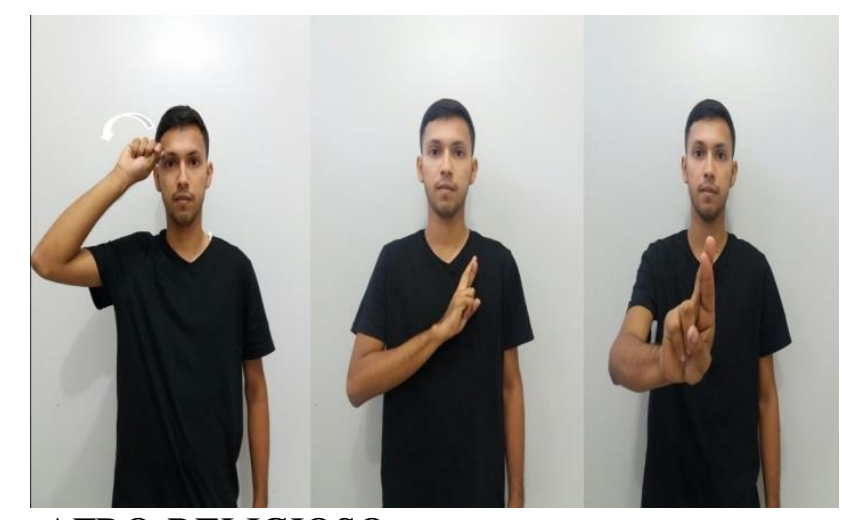

AFRO-RELIGIOSO

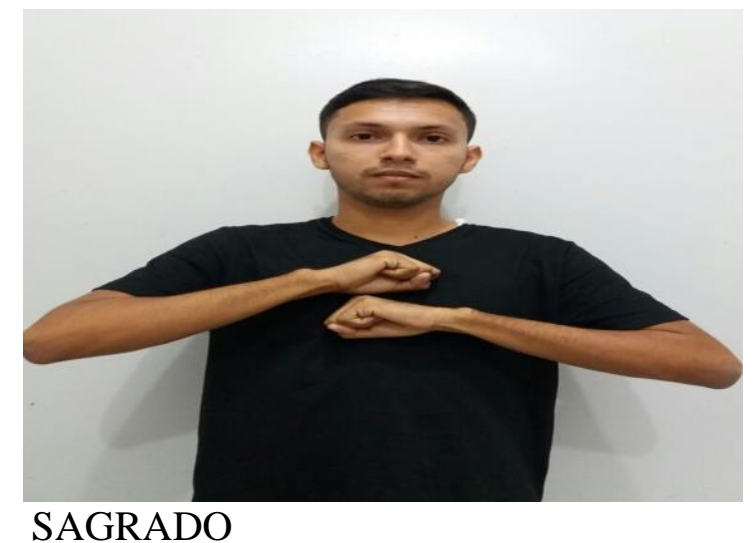

Revista Periferia, v.10, n.1, p. 100 - 119, Jan./Jun. 2018 

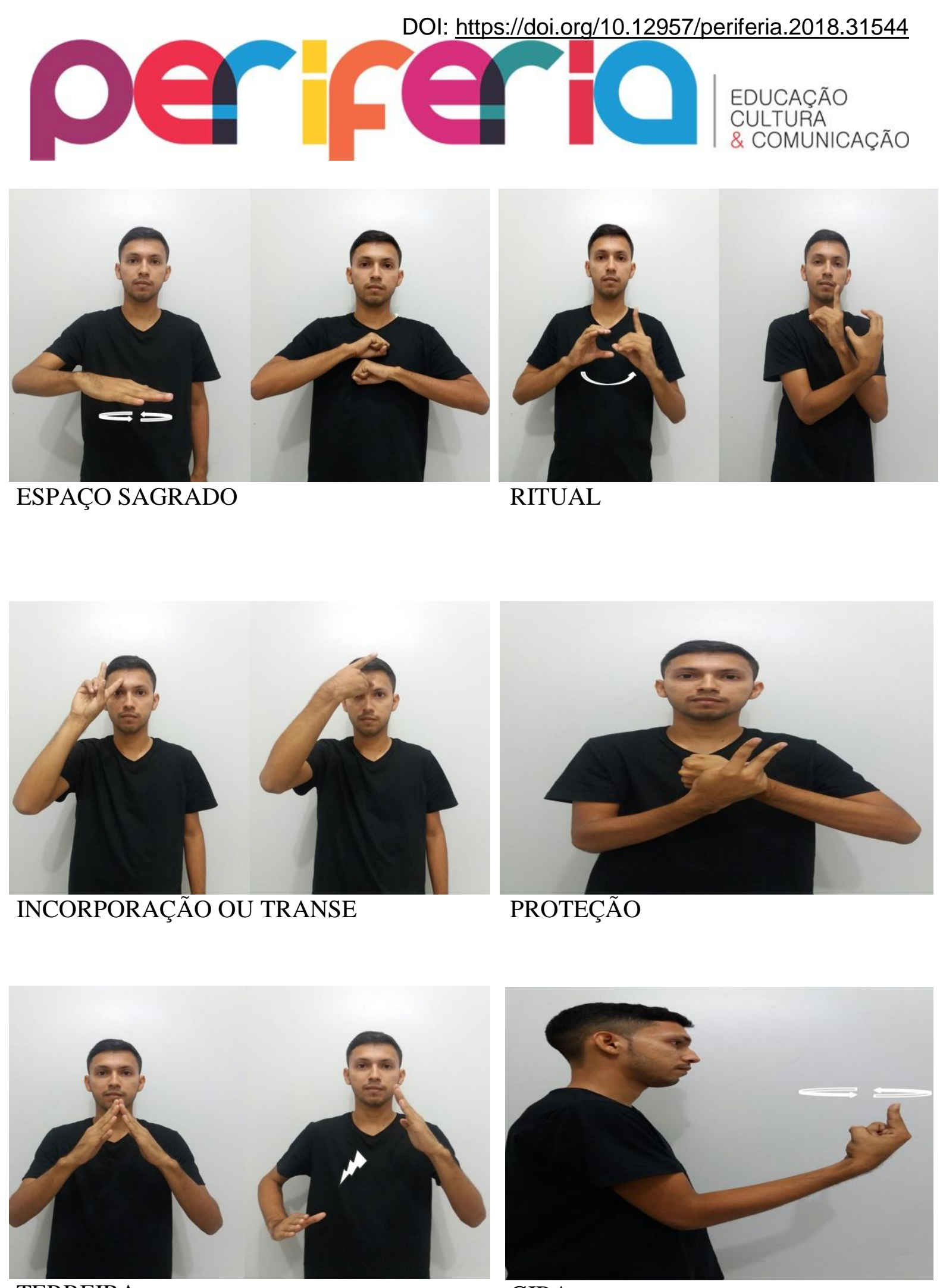

TERREIRA

GIRA

\section{CONSIDERAÇÕES FINAIS}

Essa pesquisa objetivou demonstrar não apenas o conhecimento de alguns aspectos importantes sobre como as representações das guias refletem-se na identidade 


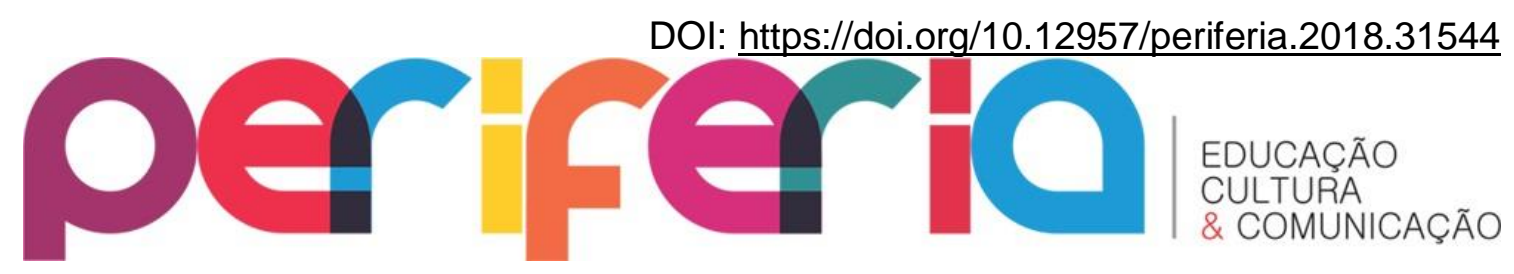

religiosa do médium surdo, sendo que nesse caso, este indivíduo interage entre três culturas, o Tambor de Mina, a cultura ouvinte e surda, mas também se evidenciou como procede-se a manifestação do sagrado, mediante a sua interpretação desses adereços estéticos pelo mesmo.

No cotidiano do terreiro, o médium surdo estabelece relações importantes com suas guias, onde há o questionamento de posse, mas evidenciam-se também noções de reverência, respeito, zelo, afeto e reciprocidade, em razão desses adereços estéticos conterem o mana de seus orixás, ou seja, contém energia ativa. De acordo com Silva (2008) "esses objetos revestem-se de uma aura do sagrado que devem, inclusive, ser diferenciados daqueles que os adeptos usam no cotidiano".

É imprescindível afirmar que as guias expressam representações para os adeptos, sendo que estas se constroem no cotidiano do terreiro, a partir da visão de sagrado do "eu" individual e coletivo, transformando-se em valores religiosos que são transmitidas através dos vários mecanismos de comunicação. Para o médium surdo, esse fato também ocorre a partir desse processo, só que a base do mecanismo de compreensão sustenta-se na observação visual, pois este é o fator chave que permite a criação de associações entre os elementos, principalmente para relacionar o sagrado e o terreno.

Os orixás manifestam-se também, através das guias. Para o médium surdo elas imprimem o seu "sentido", o seu "saber" e a sua "expressividade". O "sentido" parte da essência do sagrado, em toda ação do divino, de sua importância para o individual e para o coletivo. O "saber" é transmitido pela experiência com as práticas diárias no âmbito religioso no qual ele está inserido e, a "expressividade" se apresenta nas varias representações do sagrado através dos ritos, que ligam o terreno e o divino.

Nesse sentido, observou-se que a identidade religiosa do indivíduo estudado se assemelha a dos demais, pois é constituída de inúmeros valores que são transmitidos, ou seja, a troca de múltiplos saberes através da convivência com os demais adeptos, onde criaram estratégias para estabelecer a inclusão (leitura labial, a utilização de gestos e a modalidade escrita da língua portuguesa) onde buscam amenizar entraves comunicacionais e com o sagrado dentro do seu grupo religioso, visto que isso se evidencia pelo mecanismo de interpretação do médium surdo, a partir da percepção que se estabelece de maneira visuo-espacial.

\section{REFERÊNCIAS}

ANDRADE, Fernanda Maria Arruda dos Santos. Identidade e Religião: uma análise da construção da identidade religiosa juvenil. Recife: UNICAP, 2008. 


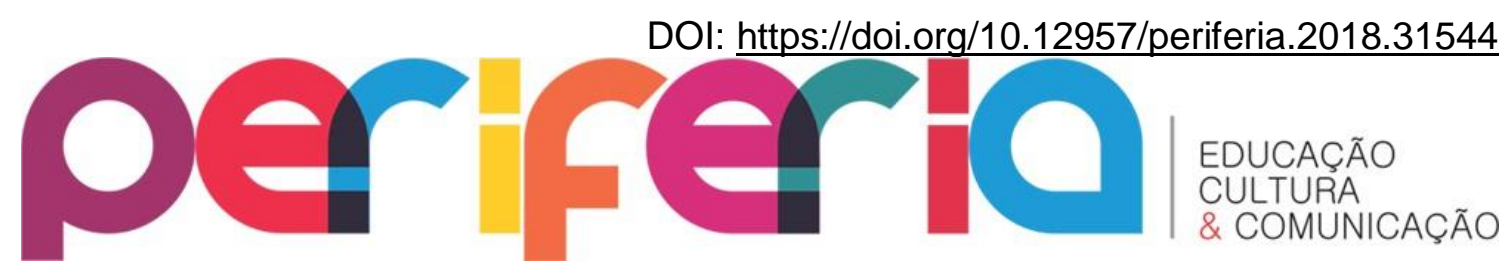

ASSIS SILVA, César Augusto. Entre a Deficiência e a Cultura: análise etnográfica de atividades missionárias com surdos. São Paulo: USP, 2011.

BUBER, Mantin. Eu e tu. Tradução, introdução e notas de Newton Aquiles Von Zuben. 10. ed. rev. São Paulo: Centauro, 2012.

CAPOVILLA. F.C.; RAPHAEL, W.D.; MAURICIO, A.C.L.. NOVO DEIT-LIBRAS: Dicionário Enciclopédico Ilustrado Trilíngue da Língua de Sinais Brasileira (Libras). 2 vol. Editora EDUSP, 2013.

CORREA, Paulo Petronilio. Agô Orixá! Gestão de uma Jornada Afro-estética-trágica: o relato de um aprendizado e de uma formação pedagógica vivida no candomblé. Porto Alegre, 2009.

FABER, Sônia Sirtoli. Hermenêutica do Rito: de interpretado a interprete. In: Congresso Estadual de Teologia. São Leopoldo: EST, v. 1 (Anais), 2013.

FERNANDES, Sueli. Educação de Surdos. $2^{\text {a }}$ Ed. Atual. Curitiba: Ibpex, 2011.

FERRETTI, Mundicarmo Maria Rocha. Desceu na Guma:o caboclo do tambor de mina de São Luís - A Casa Fanti-Ashanti. 2a Ed. São Luís: Edufma, 2000.

GASPAR, Eneida Duarte. Guia de Religiões Populares do Brasil. Rio de Janeiro: Pallas, 2002.

GEERTZ, Clifford. A Interpretação das Culturas. - 1d. 13reimpr. - Rio de Janeiro: LTC, 2008.

HALL, Stuart. A identidade Cultural na Pós-modernidade. $11^{\mathrm{a}}$ ed. Rio de Janeiro: DP\&A, 2006.

LARAIA, Roque De Barros. Cultura um conceito antropológico. $14^{\mathrm{a}}$ ed. Rio De Janeiro: Jorge Zahar Ed., 2001.

MAUSS, Marcel. Sociologia e Antropologia. Título original: Sociologie et Anthropologie. Tradução: Paulo Neves - São Paulo: Gosac Naify, 2003.

MONTEIRO, Ana Eloisa Lima, CONCEIÇÃO, Damaris de Jesus Silva da, RAMOS, Fabíola Carolina da Costa, CUNHA, Jackeline da Silva, MELO, Suellem de Carvalho. Terminologias na perspectiva da Libras com foco na criação de sinais na área das ciências da religião. In: III COLÓQUIO DO PPGCR/UEPA Belém: PPGCR/UEPA (Anais), pp. 17-25, 2016.

PEIRANO, Mariza. Rituais Ontem e Hoje. São Paulo: Jorge Zahar, 2003.

PEIXOTO, Norberto. Os Orixás e os Ciclos da Vida. Porto Alegre: BesouroBox, 2016.

SACKS, Oliver. Vendo vozes: uma jornada pelo mundo dos surdos. Tradução Alfredo B.P. de Lemos. Rio de Janeiro: Imago, 1998.

SÁ, Nídia Regina Limeira de. Cultura, poder e educação de surdos. Manaus: Universidade Federal do Amazonas. 2002.

SCHELP, Patrícia Paula. Pensar o Presente da Educação de Surdos a Partir de Leituras e Interpretações do Passado: perspectivas de inclusão nas escolas de ensino regular. Londrina, 2009. (Anais do V Congresso Brasileiro Multidisciplinar de Educação Especial).

SILVA, Reginaldo Conceição da. "Na Gira da Umbanda": exercício etnográfico sobre expressões de afrorreligiosidade na "fronteira" e no Terreiro da Cabocla Jurema em Tabatinga, Amazonas. Dissertação (Mestrado) - Curso de Cartografia Social e Política da Amazônia, Universidade Estadual do Maranhão. São Luís, 2016.

Revista Periferia, v.10, n.1, p. 100 - 119, Jan./Jun. 2018 


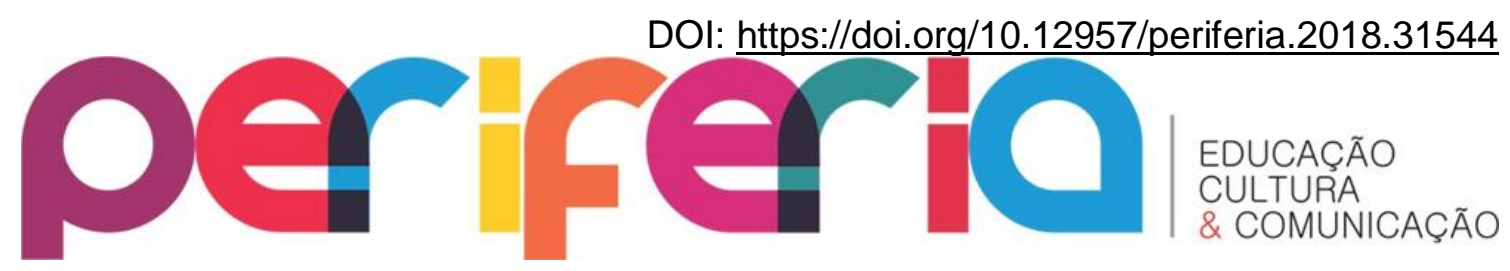

SILVA, Vagner Gonçalves da. Arte Religiosa Afro-brasileira: as múltiplas estéticas da devoção brasileira. Debates do NER, ANO 9, Porto Alegre, 2008.

SKLIAR, Carlos. Os Estudos Surdos em Educação: problematizando a normalidade. In: SKLIAR, Carlos (Org.). A Surdez - Um Olhar Sobre as Diferenças. Porto Alegre: Mediação, 2005. 